\title{
AC 2012-3955: REGIONAL MULTI-ORGANIZATIONAL APPROACH TO K-12 STEM PROMOTION
}

\author{
Dr. John Louis Vadnal, Liberty University
}

John Vadnal earned a B.S. in civil engineering from the University of Florida, and a M.S. in mechanics and hydraulics, a M.S. in applied mathematics, and a Ph.D. in mechanics and hydraulics from the University of Iowa. As a graduate student, he studied engineering during one summer at the Von Karman Institute of Fluid Dynamics in Brussels, Belgium, and for a year at Kyoto University, Japan. He worked 10 years as an engineer for the Tennessee Valley Authority (TVA), Duke Power Company, and the U.S. Army Corps of Engineers. He has taught engineering full-time for six years, with two years at the University of Evansville, Ind., and four years at Liberty University, Va. (where he is currently employed). He has been actively involved in promoting and organizing STEM outreach activities, particularly TEAMS and Vex Robotics competitions for high school students. He is an Adjunct Math Instructor at Central Virginia Community College and former board member of the Region 2000 Technology Council. Vadnal has an additional 11 years of academic and administrative experience as Chair of the Department of Science and Mathematics at Tennessee Temple University, Academic Dean and Graduate Program Director at Trinity Baptist College, and Associate Dean of the General Education component of the Distance Learning Program at Liberty University. He has taught 47 different college courses.

\section{Ms. Barbara Eileen Bragg, Ranken Technical College}

Barbara Bragg is currently the STEM Pathways Development Coordinator at Ranken Technical College in St. Louis, Mo. She has developed and led numerous STEM educational programs for more than seven years, serving secondary students and educators in both Lynchburg, Va., and now St. Louis, Mo. Those programs include summer academies for middle school and high school students, FIRST Lego League tournaments, technology fairs, and VEX Robotics. Prior to joining Ranken, she held the position of Career Pathways Coordinator at Central Virginia Community College, where she worked with regional educators, local colleges, and business and industry to promote technical careers to youth in Central Virginia. She holds a bachelor's of arts in business administration with a management emphasis from Mary Baldwin College.

\section{Jonathan M. Whitt C.Ec.D., Virginia's Region 2000 Technology Council}

Jonathan Whitt is the Executive Director of the Region 2000 Technology Council, a position he has held since 2003. Whitt works closely with Technology Council members, representatives from the region's schools, colleges and universities, and representatives of local, state, and federal government to assist and champion initiatives that bring value to the council's members and the citizens of Region 2000. $\mathrm{He}$ has been a key player in the development of several regional technology-based economic development projects, including the creation of the Region 2000 Partnership, the Center for Advanced Engineering and Research, and the Future Focus Educational Foundation. Prior to his position with the Region 2000 Technology Council, Whitt was Co-founder and CEO of NetWave Internet, a pioneer in the deployment of wireless broadband networks. NetWave's service area encompassed the Lynchburg and Roanoke, Va., markets. Whitt is a long-time advocate for broadband deployment and STEM education initiatives, having served on numerous committees and workgroups related to these issues. Whitt has also been an active entrepreneur and technologist, with four business start-ups to his credit, two of which were technology companies. He has also worked for the following Region 2000 companies: Babcock \& Wilcox, First Brands, Parker Powertrain, and Waytec Electronics. Whitt serves on numerous boards of directors and regional committees and holds professional certification as a Certified Economic Developer (CEcD). Whitt lives in Forest, Va., with his wife Jennifer and two children. 


\title{
Regional Multi-Organizational Approach to K-12 STEM Promotion
}

\begin{abstract}
This paper demonstrates how two local engineering firms (with international reach), a regional technology council, a community college and the Engineering School of a local university have partnered to offer and promote Science, Technology, Engineering and Mathematics (STEM) activities at the K-12 level in a 2000-square mile region. Their STEM outreach efforts have concentrated not only on reaching principals, teachers and students at traditional city/county, private and Christian elementary, middle school and high schools, but also numerous home school groups, a center for at-risk youth, and a house for unwed mothers (which are predominantly high-school aged). These interactions have resulted in the sharing of resources (material and financial), talent (particularly for judges, mentors and student volunteers) and facilities.
\end{abstract}

In 2003, a National Science Foundation grant was acquired by the community college to help promote STEM in the K-12 schools. Since then, this grant has provided the impetus for several organizations to work together and initiate the following STEM outreach activities: Junior FIRST LEGO League; FIRST LEGO League; a STEM-oriented website and magazine for youth; Summer Academies and Camps; Future Focus EXPOs; VEX Robotic competitions; and Junior Engineering Technical Society (JETS) Tests of Engineering Aptitude, Mathematics and Science (TEAMS) competitions.

Significant impacts of these STEM activities have been measured at several levels. Participation among students and schools have doubled and tripled at most of these events in the past several years, and have allowed a few teams to advance to national competitions or attain the top divisional ranking in the nation. One of the students who competed on a winning robotics team was awarded a $25 \%$ tuition scholarship and is currently a junior majoring in Electrical Engineering at a local university. A particular collaboration was recognized and awarded at the International Economic Development Council, Excellence in Economic Development Awards in September 2011. These activities are dedicated to helping educate local students and promoting regional career opportunities in the STEM fields, which are expected to experience a $21 \%$ growth in the region by $2016 .{ }^{1}$

The paper presents the main organizations partnering in the offering and promotion of STEM outreach activities in the region, a description of each of the activities and their participation levels, a summary of the cooperating efforts and benefits achieved, and recommendations for how other people interested in STEM outreach can successfully pursue offering and promoting these events.

\section{Overview}

One can hardly listen to or read the news lately without hearing or seeing something about the inadequate state of education within the United States K-12 school system, particularly in 
reference to science, technology, engineering, and math (STEM). The Information Technology Industry Council reports:

"Our nation's children are falling further and further behind their international peers in almost every area of STEM education. ... Most American middle-schoolers would rather do chores, eat vegetables, or go to the dentist than do math homework. ... An American high school student has a 70\% chance of being taught English by a teacher with an English background, but only has a $40 \%$ chance of being taught chemistry by a teacher with a chemistry background.",2

As evidenced in the National Research Council's report, Successful K-12 STEM Education: Identifying Effective Approaches in Science, Technology, Engineering and Mathematics, there are various approaches being used to improve STEM education. Several main approaches include: (1) establish schools which concentrate on STEM education for its students; (2) train qualified educators in best practices for STEM teaching and learning; and (3) educate educational and political leaders, parents and communities on the need for improvements in STEM education. ${ }^{3}$ Examples across the nation typically focus on these approaches.

As an example, Battelle and the Ohio Business Roundtable were the primary entities who created the nation's first-ever statewide network for STEM education in Ohio with assistance from the Bill \& Melinda Gates Foundation. Ohio's first STEM school was opened in 2007. Ohio's Governor Ted Strickland allocated "\$13 million to establish STEM schools and programs in Ohio." ${ }^{4}$ Consequently, a $\$ 12$ million grant was awarded by the Bill \& Melinda Gates Foundation to develop a "network of STEM hubs, hosts, platform schools and programs to infuse STEM literacy and disseminate knowledge throughout the state." In 2008, the Ohio STEM Learning Network (OSLN) was created. A total of $\$ 200$ million was obtained to fund:

* college scholarships for aspiring STEM majors

* research grants for STEM college faculty

* training and professional development for STEM classroom teachers, and

* planning grants and support for new STEM schools and programs. ${ }^{4}$

Since then, funding has been provided to support a total of five regional STEM innovation hubs, 26 K-8 STEM Programs of Excellence, and eight STEM schools. Most recently, STEM networks have been started by Battelle and the Bill \& Melinda Gates Foundation in four other states (California, New York, North Carolina, and Texas) due to the success and growth of OSLN.

Drew has compiled a comprehensive summary of the current state of STEM education in the United States (US) and several alarming rankings: ${ }^{5}$

US 15 -year olds rank $24^{\text {th }}$ in the world in math literacy (2003)

US 15-year olds rank $19^{\text {th }}$ in the world in science literacy (2003)

US ranks $41^{\text {st }}$ in the world in the percentage of its math teachers having math degrees (47.3\%)

Drew presents eight steps for transforming STEM education in the United States: 
1. Leadership

2. Evaluation

3. Better teachers

4. High expectations

5. Committed mentors and role models

6. The value of a college education

7. Closing the achievement gaps

8. Revitalizing university research ${ }^{5}$

Improving STEM education will require a close interaction among organizations, particularly K12 institutions, higher education institutions, and private industry (e.g., engineering companies). Steps that organizations can take to assure an effective working relationship are outlined in the article "What It Takes to Work Together: The Promise of Educational Partnerships". 6 The article presents three general types of partnerships (limited, coalition, and collaborative) which allow organizations to share expertise and leverage limited resources. The article also presents seven steps to partnering, which are discussed and applied herein. ${ }^{6}$

1. Identify a shared concern about a real problem. The problem here is how to offer $\mathrm{K}-12$ students opportunities to participate in STEM outreach activities.

2. Find the right mix of participants. As will be shown below, a Technology Council, community college, university and a couple engineering companies have taken an active interest in organizing and hosting STEM outreach activities.

3. Develop an appropriate organizational structure. At the present time, the participating organizations successfully interact and cooperate well without any formal structure.

4. Specify the roles and responsibilities of leaders and participants. These roles and responsibilities are handled by the organization hosting each STEM outreach event.

5. Carry out the partnership's activities. This has been done with the offering of the numerous STEM outreach events described below.

6. Evaluate the partnership's structure and activities. This is done solely by the hosting organization to assess how the event went and what could be improved next time.

7. Confront problems and use them as opportunities to build relationships among partners. Since different individual organizations host these STEM outreach events, there have not been any problems between partners.

Kanter presents a list of eight characteristics of successful relationships, which are discussed and applied herein. ${ }^{7}$

1. Individual excellence. All the cooperating organizations in this effort have something of value to contribute. 
2. Importance. Offering of STEM events is important to the cooperating organizations.

3. Interdependence. The organizations can accomplish more working together than alone.

4. Investment. The organizations invest time, resources, and personnel with other organizations in the offering of STEM events.

5. Information. There are open lines of communication among the organizations.

6. Integration. The organizations have the needed connections to work together smoothly.

7. Institutionalization. There are clear responsibilities for participating organizations in each of the STEM events.

8. Integrity. The participating organizations have a mutual respect toward each other.

These eight "I's" have been presented within the criteria and recommendations for successful public-private partnerships in education in England. ${ }^{8}$ They have also been presented in a case study of a collaboration between a public school district and a nonprofit organization. ${ }^{9}$

Formal definitions of working arrangements are readily available. The National Network for Collaboration clearly defines and distinguishes among the following five working relationships:

1. Networking

2. Cooperation or Alliance

3. Coordination or Partnership

4. Coalition

5. Collaboration ${ }^{10}$

Berliner defines and distinguishes among the following four ways of partnering (which were also presented by Davies and Hentschke ${ }^{8}$ ):

1. Networking

2. Coordinating

3. Cooperating

4. Collaborating ${ }^{6}$

Klipsch proposes five steps for ensuring an enduring school / community collaboration:

1. Assess the climate

2. Build relationships

3. Design processes for communication

4. Write a formal agreement

5. Collaborate ${ }^{9}$ 
For the purpose of this paper, terms such as collaboration and partnering are used interchangeably and simply describe "two or more individuals working toward a desired outcome." 10 The participating organizations presented herein have informally developed good working relationships to promote STEM activities in the region without the requirement of a formal agreement. These relationships have developed naturally from the united desire and acknowledged need to promote STEM activities in the region. This partnering has been productive without following the often-mentioned forming, storming, norming and performing steps to collaboration development. ${ }^{9}$

This paper presents a multi-organizational approach to offer and promote STEM activities to K12 students in the region. The intent is that if students can be educated, participate and compete in various STEM activities, they will be more open to explore STEM-related education and pursue critically-needed STEM-related employment opportunities in the region.

According to the U.S. Department of Commerce, the predicted growth and outlook for STEMrelated jobs is very promising and inviting, as can be seen in the statistics below:

* $\quad$ STEM occupations are projected to grow by 17 percent from 2008 to 2018 , compared to 10 percent growth for non-STEM occupations

* $\quad$ STEM workers earn about 25 percent more than their non-STEM counterparts

* STEM workers are less likely to experience joblessness than their non-STEM counterparts $^{11}$

Also reported is that STEM "workers drive our nation's innovation and competitiveness by generating new ideas, new companies and new industries". ${ }^{2}$ Hence, it is critical to the economic well-being of the US to help reach, inspire, educate, and train current young people to fill these projected employment opportunities.

In Virginia's Region 2000, the average projected employment growth is projected to be 20.9 percent among the top 10 STEM industries between 2006 and 2016. ${ }^{1}$ Consequently, and although miniscule in comparison to what has been developed and achieved by the OSLN, offering and promoting STEM outreach activities through a partnering of multiple organizations is a step in the right direction toward introducing, educating and inspiring regional youth.

This paper first highlights the primary organizations which are promoting STEM activities in the region. A summary of the various STEM activities are then presented. The paper then overviews the partnering which has allowed these activities to be offered and promoted, and the benefits derived. The paper concludes with recommendations for how other parties can get involved in offering STEM-related activities to K-12 students in their regions.

\section{Regional Organizations}

The city of Lynchburg combined with the four counties of Amherst, Appomattox, Bedford and Campbell in south-central Virginia is commonly referred to as "Region 2000". Overall characteristics of the region based on the latest community profile (using 2010 census data) are shown below: 
Population of 252,634

* Distribution by race/ethnicity is:

White $(77.1 \%)$

Black or African American (17.4\%)

Hispanic or Latino (2.1\%)

All others (3.4\%)

* Population of 5 to 19 year olds is 50,079 (20\%)

Distribution of 5 to 19 year olds is $50 \%$ male and $50 \%$ female

Population is expected to increase by $2 \%$ between 2010 and 2020 , then by $6 \%$ between 2020 and 2030

Education level of population 25 years and over (based on 2000 Census):

Other $(24.0 \%)$

High School Grad / GED (32.0\%)

Some College (19.6\%)

Associate's Degree (5.6\%)

Bachelor's Degree (12.3\%)

Post Graduate Degree $(6.5 \%)^{13}$

Within this region are several organizations which have partnered to offer and promote various STEM activities to its K-12 students: Region 2000 Technology Council, Central Virginia Community College, Liberty University, AREVA and Babcock \& Wilcox. A brief overview of each of these regional organizations is provided herein.

Region 2000 Technology Council "works to foster an environment that stimulates innovation and growth of technology-focused organizations" in the region, and in six primary technology areas: Energy; Engineering; Information Technology; Manufacturing; Pharmaceutical; and Wireless Technologies. ${ }^{14}$ The Region 2000 Technology Council has been active in helping to promote all the STEM outreach activities described in this paper. In 2009, the Region 2000 Technology Council established a non-profit Future Focus Foundation having a Managing Director to help "create an environment and sustainable programs in the region's K-12 schools that enhance Science, Technology, Engineering and Math career interest". ${ }^{14}$

More information about the Region 2000 Technology Council can be obtained at its website. ${ }^{14}$

Central Virginia Community College (CVCC) is a two-year institution located in Lynchburg, Virginia and serves a geographical region having more than 243,000 people. In 2003 , the National Science Foundation awarded CVCC a grant for its "Priming the Pipeline" project to expand regional K-12 STEM activities related to nuclear technologies and wireless communications. CVCC partnered with the Region 2000 Technology Council to develop a unique program denoted "Grow Your Own Workforce" which exposes students to careers available in the region, particularly those related to STEM disciplines. This workforce development program seeks to find, educate, and train workers for the high-growth, high-wage science, technology, engineering and math careers in the region, which are expected to realize a 20.9\% growth between 2010 and 2016. ${ }^{\text {I }}$ This program has received two national awards and 
achieved international recognition through the 2011 "Partnerships with Educational Institutions" award from the International Economic Development Council. ${ }^{15}$

More information about CVCC can be obtained at the college's website. ${ }^{16}$

Liberty University is a religiously-oriented, private, coeducational, comprehensive institution located in Lynchburg, Virginia and offers 140 undergraduate and graduate programs. With about 12,000 students on its 6500 -acre campus and more than 65,000 online students, it is the world's largest Christian university and the "nation's eighth-largest four-year university". ${ }^{17,18}$ The university established a School of Engineering and Computational Sciences (SECS) in 2007 and began offering Bachelor of Science programs in Computer Engineering, Electrical Engineering, and Industrial \& Systems Engineering. SECS had its first graduates in the Electrical Engineering and Industrial \& Systems Engineering programs in May 2011. Liberty University is the second largest employer in the region. ${ }^{19}$

As will be discussed below, SECS joined forces with CVCC and the Region 2000 Technology Council to help offer, promote and assist with STEM outreach activities in the region. As part of this effort, SECS has attempted to invite and include as many high school students as possible when offering and promoting these events. Its current contact list, which has been developed during the past three years, has 33 contacts and is used when promoting any STEM activity for high school students. The list comprises the following representation:

* 9 county high schools

$* 2$ city high schools

* 1 county Science \& Technology contact person

* 1 county technical center

* 6 Christian high schools

* 4 home school groups based in four churches

* 4 military boarding schools

* 1 all-girl's preparatory school

* 1 Family Development Center for at-risk youth

* 1 home for unwed mothers

* 1 governor's school

* 1 city technology council

* 1 local community college

Note that all contacts are grateful to be informed of the STEM outreach events although not all contacts produce participants.

More information about Liberty University can be obtained at the university's website. ${ }^{20}$

AREVA is an international engineering company based in France with 50,000 employees worldwide, 6,000 employees in the U.S, and has three offices in the city of Lynchburg. The focus of the company is power generation, especially within the nuclear power industry. The company is also expanding into renewable energies, such as wind, solar, bioenergies, hydrogen and storage. The company recruits 3,000 people a year for multiple positions: engineers, 
designers, researchers; manufacturing, production and maintenance personnel; health, safety and environmental professionals; sales and legal professionals and product managers; and communications, finance, human resources, and IT support roles. AREVA recently won the Engineering Project of the Year Award at the $13^{\text {th }}$ Annual Platts Global Energy Awards held in

New York City. ${ }^{21}$ AREVA is the fourth largest employer in the region. ${ }^{19}$

More information about AREVA operations in the United States can be obtained at the company's website. ${ }^{22}$

The Babcock \& Wilcox Company is headquartered in the United States and dedicated to excellence in the delivery of advanced energy and operational solutions. The company is divided into four groups which concentrate on: nuclear energy; nuclear operations; power generation; and technical services. The company's power generation systems and equipment are in over 90 countries and in more than 800 utilities and industries. The company has a total of nearly 20,000 employees and has six unit offices in the local region. The Babcock \& Wilcox Company is the third largest employer in the region. ${ }^{19}$

More information about the Babcock \& Wilcox Company can be obtained at the company's website. $^{23}$

There are a handful of other engineering organizations in the region which have also contributed in various ways in supporting STEM outreach activities. The two companies featured here are the largest and the primary engineering contributors to these events.

\section{STEM Outreach Activities}

Below is an outline of most of the STEM activities that are being offered and promoted to K-12 students in the region. These descriptions present an overview of each activity, the main organization(s) offering and promoting the event, the participation levels, and any form of assessment or relevant anecdotal data.

FIRST LEGO: FIRST (For Inspiration and Recognition of Science and Technology) LEGO is a robotics program for 9 to 14 year olds (9 to 16 year olds outside of Canada, US and Mexico). FIRST was founded by accomplished inventor Dean Kamen in 1989. The intent of the program is to excite students about science and technology by providing the opportunity to work in teams and research, design, build, and experiment with the LEGO robots. In doing so, the students "live the entire process of creating ideas, solving problems, and overcoming obstacles, while gaining confidence in their abilities to positively use technology". ${ }^{24}$ Teams can comprise up to 10 students. Starting with only 210 teams in the 1998 pilot year, there are now over 20,000 teams in over 60 countries.

The competition event is organized and promoted by CVCC but held at Timberlake Christian Schools and likely the largest competition of this event in the state. Again, collaboration between institutions was critical for having a successful event. About 22 college students from SECS volunteered to help with the most recent event. Here are just a few of the positions needed to run the event: Friday night general set-up; Saturday evening general breakdown; practice pit 
managers; judges for robot designs \& teamwork categories; staffing for registration / information tables; build and breakdown field set-up kits; traffic control and parking; historian's assistant; table setter; judge's assistant and queuer; referees; field managers; and scorekeepers.

The table below summarizes the number of teams and students participating in this STEM outreach activity.

\begin{tabular}{|c|c|c|}
\hline Year & \# of Teams & \# of Students \\
\hline 2006 & 8 & 40 \\
\hline 2007 & 24 & 162 \\
\hline 2008 & 32 & 229 \\
\hline 2009 & 32 & 250 \\
\hline 2010 & 30 & 210 \\
\hline 2011 & 36 & 270 \\
\hline
\end{tabular}

Historically, the ratio of boys to girls for this local event has been 3 to 1 .

More information about the FIRST LEGO competitions can be obtained at the FIRST LEGO League website. ${ }^{25}$

Future Focus Expo: Future Focus Expo is a trade-show format that educates middle and high school students and their parents about local industries, institutions and career opportunities, but emphasizes science and technology careers. The Expo offers competitive hands-on STEMrelated Challenges (e.g., aviation, technology) at the event and awards the winning students.

This event requires significant coordination since it is promoted by the Region 2000 Technology Council, hosted by Liberty University, and sponsored by about ten organizations, including CVCC, AREVA, and the Babcock \& Wilcox Company.

Although there are more than only STEM careers portrayed at the event, its main benefit is to educate both students and parents about careers that are available in the region. Surveys distributed to parents and students consistently demonstrate the following results (Jonathan Whitt, personal communication, January 3, 2012):

* Over $90 \%$ of students agree that there was a career for them in this region after attending the Expo

* Over $90 \%$ of parents agree that the Expo was beneficial in helping their child identify a career path in the region

* Over $90 \%$ of parents agree that the Expo was beneficial in understanding what schools and training are required for each career

* Over $98 \%$ of parents agree that the Expo was beneficial in increasing their awareness of jobs in the region

The table below summarizes the number of students and exhibitors participating in this STEM outreach activity. 


\begin{tabular}{|c|c|c|}
\hline Year & \# of Students & \# of Exhibitors \\
\hline 2006 & 159 & 48 \\
\hline 2007 & 815 & 56 \\
\hline 2008 & 500 & 76 \\
\hline 2009 & 1200 & 62 \\
\hline 2010 & 2500 & 70 \\
\hline
\end{tabular}

More information about Future Focus Expo can be obtained at its website. ${ }^{26}$

Get Set Magazine and Website: The Region 2000 Technology Council oversees the publication and distribution of Get Set Magazine (The Student's Guide to Awesome Careers in Central Virginia), which is distributed to 10,000 regional middle and high school students at no charge. The vibrant and colorful magazine presents testimonies and informative articles of various STEM activities and career opportunities in the region, while concentrating on the high-tech careers. A related website provides students the opportunity to explore information about hightech careers in the region. The website contains stories of teen successes, lists of fun activities and events, summaries of school programs, information on job training, preparations for college, insights into college studies, and overviews of local companies. There are also links to the websites of major sponsors, events and activities, resources and programs, local colleges and universities, and area companies.

More information about Get Set Magazine and website can be obtained at its website. ${ }^{27}$

Junior FIRST LEGO: Junior FIRST (For Inspiration and Recognition of Science and Technology) LEGO is a program for 6 to 9 year olds involving "LEGO elements and moving parts to build ideas and concepts and present them for review". ${ }^{28}$ The intent of the program is to stir the curiosity of students about the wonders of science and technology through a hands-on program. This program was piloted in 2004 and is more recent than FIRST LEGO. There is an annual team challenge that is solved using research, critical thinking and imagination. Teams are comprised of two to six children.

This competition event is organized and promoted by CVCC and held at Timberlake Christian Schools.

The table below summarizes the number of teams and students participating in this STEM outreach activity.

\begin{tabular}{|c|c|c|}
\hline Year & \# of Teams & \# of Students \\
\hline 2010 & 20 & $\sim 400+$ \\
\hline 2011 & 26 & $\sim 400+$ \\
\hline
\end{tabular}

More information about the Jr. FIRST LEGO competitions can be obtained at the Junior FIRST LEGO League website. ${ }^{29}$

Robotics competitions: Robotics competitions have been hosted by the Liberty University School of Engineering and Computational Sciences (SECS) in the Spring semester of the past 
four years (2009-2012). The first year (2009) was a small initial offering of a robotics competition. A home school team won that event and each member was awarded an $\$ 8,000$ engineering tuition scholarship (i.e., $\$ 2,000$ per year for four years) to Liberty University. One of the winning team members enrolled in Liberty University and is currently classified as a senior majoring in Electrical Engineering and on the Dean's List with a 3.69 grade point average. The VEX Robotics Competition was hosted the next three years (2010-2012). One of the top three teams in 2010 traveled to and competed in the 2010 VEX Robotics Competition World Championship in Dallas, TX on April 22-24. The top three teams in the 2012 event automatically qualified to compete in the 2012 VEX Robotics Competition World Championship, which is held at the Anaheim Convention Center, Anaheim, CA, April 18-21, 2012.

The first VEX Robotics competition in 2010 would not have been successful without the collaboration of several organizations, and especially Brad Lauer at Innovation First, Inc., who came to run and oversee the event. CVCC loaned its VEX robotics playing field for the competition, recruited and registered 11 of the 21 teams. Some of the electronic equipment for the event was borrowed from the Halifax County STEM Center in Halifax, Virginia. The Babcock \& Wilcox Company supplied all the judges for the event. The Region 2000 Technology Council scheduled the guest speaker for the event. Both AREVA and the Babcock \& Wilcox Company are active in and have helped sponsor (with monetary donations) this event.

Due to the local interest in and demand for robotics technology, a couple local high schools now offer robotics classes or a "Robotics Club", which is a welcome addition to the more traditional Chess, Drama and Spanish Clubs.

The table below summarizes the number of schools, teams, and students participating in this STEM outreach activity.

\begin{tabular}{|c|c|c|c|}
\hline Year & \# of Schools & \# of Teams & \# of Students \\
\hline 2009 & 8 & 13 & 34 \\
\hline 2010 & 15 & 21 & 78 \\
\hline 2011 & 13 & 23 & 114 \\
\hline 2012 & 10 & 27 & 135 \\
\hline
\end{tabular}

Additional information about the VEX Robotics competitions can be obtained at their website. ${ }^{30}$

Summer Academies: CVCC is the primary host and organizer for the Summer Academies. The intent of the academies is to educate and inspire middle and high school students about the career opportunities available in the region. Activities associated with the camps include a planned curriculum, skill-building activities, industry tours, and guest speakers. There are Middle School Career Academies for rising $6^{\text {th }}, 7^{\text {th }}$ and $8^{\text {th }}$ graders, and High School Career Academies for rising $9^{\text {th }}$ and $10^{\text {th }}$ graders. Although the Academies feature a variety of careers ranging from Culinary Arts to Motorsports Technologies, a number of them focus on STEM disciplines. A list of the relevant STEM-related academies is provided below. 
Advanced Manufacturing

Aviation Technology

Experiments Gone Wild

(e.g., biology, chemistry, physics and earth science)

Health Technologies

Information Technology

Nuclear Technologies

Women in Engineering
Advanced Engineering

Advanced Manufacturing

Construction Technology

Wireless Technologies

A production of this magnitude could not be accomplished without the collaboration of many parties, including seven sponsors and 32 contributors. Similar to other STEM outreach activities in the region, The Babcock \& Wilcox Company is a main sponsor, and AREVA, Liberty University, and the Region 2000 Technology Council are valuable contributors.

The table below summarizes the number of camps and students participating in this outreach activity.

\begin{tabular}{|c|c|c|}
\hline Year & \# of Camps & \# of Students \\
\hline 2001 & 3 & 32 \\
\hline 2002 & 4 & 46 \\
\hline 2003 & 6 & 43 \\
\hline 2004 & 6 & 51 \\
\hline 2005 & 7 & 94 \\
\hline 2006 & 9 & 120 \\
\hline 2007 & 11 & 157 \\
\hline 2008 & 15 & 208 \\
\hline 2009 & 19 & 218 \\
\hline 2010 & 19 & 240 \\
\hline 2011 & 20 & 240 \\
\hline
\end{tabular}

Historically, the distribution between boys to girls for this local event has been approximately $60 \%$ boys and $40 \%$ girls.

Additional information about these Summer Career Academies can be obtained at its website. ${ }^{31}$

Summer Camps: The Liberty University SECS provided the facilities to offer a one-week summer engineering camp to 60 fifth and six graders in both 2010 and 2011 as a STEM outreach activity. Two local engineers hosted, organized and ran the week-long camps. The camps offered students the opportunities to participate in various hands-on experiments and design experiences, field trips to local engineering companies, and hear guest speakers who described what life is like as an engineer, and what engineers do in a typical day.

More information about the Summer Camps can be obtained by contacting the Liberty University School of Engineering and Computational Sciences at 434-592-7150. 
TEAMS competition: The Liberty University SECS hosted a TEAMS competition for high school students the past four years (2009-2012). TEAMS (Tests of Engineering Aptitude, Mathematics and Science) is an annual, theme-based, collaborative competition which gives students in grades 9-12 an opportunity to use the practical applications of math and science to answer engineering questions about everyday world challenges. The annual themes for the past five years have been:

2008: Athletic Events

2009: Theme Parks

2010: Water, Water Everywhere

2011: Smarter Energy. Cleaner Planet.

2012: Engineering Healthier Lives

The 2012 theme was particularly relevant to biomedical engineering and presented numerous problems dealing with practical topics: heart valve replacement surgeries; prostheses for hip replacements; biomechanics; drug design \& development; dental implants; fluid dynamics \& heat transfer; data management systems; and clinical trials.

One participating team in 2010 placed first in the nation in its grade/level and division. All four schools participating in 2011 had one of their teams place first in the state in their respective grade/level and division. Nationally, 1,229 teams competed in the 2011 event. A total of 18 teams competed in the state of Virginia.

TEAMS is an effective means of educating high school students about engineering, as shown in its 2010 report (Megan Balkovic, personal communication, June 2, 2010):

* $92 \%$ reported TEAMS made them understand the important role engineers play in society.

$* 92 \%$ reported TEAMS increased their knowledge about what engineers do.

* $88 \%$ reported TEAMS increased their confidence in their ability to participate in engineering activities.

* 88\% reported TEAMS increased their confidence in their ability to solve complex problems.

* $70 \%$ reported TEAMS made them consider an engineering major or career.

When asked about their plans to pursue an engineering major or career, student responses in the immediate post survey revealed $43 \%$ were considering engineering, $29 \%$ were not considering engineering, and $27 \%$ were undecided. A data analysis of the students reporting they were not considering engineering or were undecided revealed:

* Of the $29 \%$ of students who stated they "were not" considering engineering: $87 \%$ noted a slight to great impact in their knowledge about what engineers do $78 \%$ noted a slight to great impact in their confidence to participate in engineering activities

* Of the $27 \%$ of students who reported being undecided about engineering:

93\% noted a slight to great impact in their knowledge about what engineers do $90 \%$ noted a slight to great impact in their confidence to participate in engineering activities 
Students reported the reasons for participating in TEAMS as:

$27 \%$ to understand math and science concepts

$62 \%$ because a teacher invited them

$37 \%$ to learn about engineering

$13 \%$ to meet others with similar interests

$65 \%$ to have fun

$12 \%$ because parent/guardian encouraged them

$43 \%$ wanted it on college applications

$29 \%$ to compete against others

The table below summarizes the number of schools and teams participating in this STEM outreach activity.

\begin{tabular}{|c|c|c|}
\hline Year & \# of Schools & \# of Teams \\
\hline 2009 & 1 & 2 \\
\hline 2010 & 2 & 3 \\
\hline 2011 & 4 & 8 \\
\hline 2012 & 4 & 9 \\
\hline
\end{tabular}

Table 1 tabulates the results of a survey given to and completed by 64 of the 66 students participating in the 2012 event. A summary of notable observations from the surveys are provided below:

$75 \%$ male; $25 \%$ female

$44 \%$ were first-time participants

$100 \%$ planned to attend college

$60 \%$ were very likely and $22 \%$ were somewhat likely to pick a STEM major in college

$34 \%$ were very likely and $13 \%$ were somewhat likely to pick an engineering major in college

$13 \%$ of the responses indicated nuclear engineering as being of most interest

$25 \%$ had never been to Liberty University

$40 \%$ did not know Liberty University had an engineering school

$36 \%$ indicated the competition was fun, $22 \%$ educational, and $39 \%$ challenging

$91 \%$ would recommend this competition to their friends

$57 \%$ selected working as a team for what they liked most about the competition

$34 \%$ selected they were "very much so" aware of problems that engineers solve as a result of the competition

$46 \%$ indicated that a career in engineering would be rewarding

TEAMS is currently offered through the Technology Student Association (TSA) and was previously offered through the Junior Engineering Technical Society (JETS). Additional information about the TSA and the TEAMS competition can be obtained at its website. ${ }^{32}$

\section{Summary of Multi-Organizational Approach to K-12 STEM Promotion}

The focus of STEM outreach activities should be to provide regional K-12 students the opportunity to work in teams and produce an end result that is social, instructional, cerebral, 
gratifying, productive and fun. If these young students can "catch the vision" of what a career in any of the STEM disciplines can provide, the entire region will benefit economically and technologically from students who remain or return to the region to work, branch out to start their own businesses, and eventually employ others. Consequently, it is easier to avoid "turf" issues. The organizations work together to offer and promote the particular events that each organization is most capable of hosting in terms of personnel, facilities, funding, commitment, and passion. The organizations presented in this paper have worked well together to provide numerous and varied opportunities for STEM outreach activities at different venues and for diverse age groups.

The STEM outreach activities presented in this paper have produced numerous benefits for each of the participating parties and region.

For the Region:

* the STEM activities help educate and encourage students to seek and fill higher-skilled positions, particularly in view of the Bureau of Labor Statistics which "predicts a talent gap of 7 million skilled workers in the United States by $2016^{\prime 2}$

For the participating students:

* engineers judging the events have the opportunity to interact with, mentor and excite students

* competitions provide a opportunity for girls to participate (typically $25 \%$ ), who are traditionally under-represented in STEM careers

* $\quad$ students have fun and recommend these events to their friends

* $\quad$ students gain experience working applied problems and enjoy working in teams

* $\quad$ students are given the opportunity to participate for the first time

* $\quad$ students appreciate why attending college is important for a STEM career

* $\quad$ students become aware of challenges facing the STEM career fields

For the teachers of participating students:

* teachers obtain documented cases of why science, technology, engineering, and math are important and should be studied and appreciated by their students

* teachers can compare the achievements of their students to achievements of other students in the region, state and nation

For the parents of participating students:

* competitions provide "quality time" between the students and their parents who are typically in the stands cheering for their child and team

* the events educate parents on college and career options for their children

For the college students and institutions:

* college students helping in events gain opportunities to accept responsibility, interact with younger students in mentor roles, and accumulate community service hours (which can be a graduation requirement)

* institutions hosting events gain opportunities to recruit potential students

* events demonstrate the importance of a college education 
For the engineering companies:

* engineering organizations at local events gain opportunities to promote their organizations, develop relationships with technically-minded students, and accumulate names of students for possible internships and eventual employment of people already having roots, familiar with, and "content" in the region

\section{Recommendations}

The information in this paper has highlighted the primary STEM outreach activities which have been implemented for K-12 students in the region. Many of the events represent national and international competitions, so there are abundant resources available in nearby communities to help those who have a desire to offer and host such an event.

As with all events, there are numerous tasks to identify and assign to a responsible party. Although far from exhaustive, a basic checklist of 30 items in an approximate chronological order has been developed and can be requested from the author to aid with the planning process. Essential items from the checklist include: a team of volunteers; date, venue and rules of the competition; registration deadline and procedures; contact list of schools, home school and youth groups; fliers, announcements and media publicity; detailed event schedule of competition day; and judges, awards, door prizes and a photographer.

Colleges and universities interested in offering and promoting STEM outreach activities for regional K-12 students should develop a contact list containing all regional public, private, college preparatory, military and Christian schools and home school groups (many home school groups are based in churches). Development of the contact list can be a painstaking process trying to identify all the organizations in the region, then finding the "best" person in each organization who is interested and willing to "beat the bushes" and encourage and inspire students to participate. These contacts are typically comprised of principals, math, physics, chemistry or biology teachers. Contacts with other groups are also valuable and should be considered (e.g., Boy Scouts, Girl Scouts, 4-H Clubs, and inner-city youth groups).

Institutions sponsoring an event for the first time should plan on starting small to gain experience in the new endeavor. Host the event initially to learn what to expect, what went well, and what can be improved next time. Institutions can plan to gradually add other events that focus on different types of competitions (e.g., hands-on vs. pencil and paper) and age groups as they become more comfortable with the required activities and demands.

Competitions should emphasize the importance of teamwork, be festive, and provide a time of celebration. Door prizes determined by randomly drawn tickets add to the excitement level. Door prizes can range from t-shirts, pens, bumper stickers, backpacks, flash drives, water bottles, and gift cards (e.g., Best Buy, iTunes) to VEX Robotics kits, remote control airplanes, laptops and iPads. The more expensive prizes can be acquired through donations from vendors. All 
participating students should be considered "winners" and should return home excited about what happened at the event, what they learned, and who they met.

Anonymous surveys which are easy and quick to complete should be provided to participating students and team coaches to help "quantify" the experience, provide a means of assessment, evaluate how the event went, and identify areas of both kudos and trouble which may have occurred behind the scenes.

It would be difficult to conduct a longitudinal study to track whether the K-12 students participating in these STEM outreach events improve their grades in math and science as a result of their participation, or attend college, graduate, and become gainfully employed in a STEM career. Representatives at the college and university levels may recollect from the STEM events they help sponsor the faces and names of students who enroll in subsequent years to pursue a STEM career. Nonetheless, institutions should plan to offer and promote these STEM outreach activities for K-12 students and hope that the passion shown for the event and content material is so evident that the students cannot help but notice, and at least consider pursuing a STEM career.

$\mathrm{K}-12$ teachers, principals and administrators who are interested in having their students participate in STEM-related activities should explore what events might be available in the region. If there is a community college, college or university nearby, feel free to contact the institution to see if anyone there (e.g., faculty in the math, engineering, or science disciplines) would be interested in organizing and hosting an event.

Employees in STEM fields who have a desire to participate in STEM events should explore what events might be available in the local region. If so, contact the organization hosting the event and ask if there are any opportunities for volunteers, particularly as a judge.

City organizations and councils who are interested in helping to educate the K-12 student population in STEM careers can partner with local businesses and offer an Expo featuring exhibits, competitions, and educational literature about STEM and other career opportunities in the region.

In conclusion, the following quote was made famous by the movie Field of Dreams: "If you build it, he will come." Similarly, if organizations work together to help offer and promote STEM-related activities, the students will come to participate in them. The biggest benefit of these activities is to inspire and excite students about STEM careers. Nevertheless, if we fail, perhaps will.i.am and the multi-platinum award-winning group, The Black Eyed Peas, can succeed at getting today's youth "energized" about science, technology, engineering and math. ${ }^{33}$ They provided the halftime entertainment for 30,000 attendees at the $20^{\text {th }}$ Annual FIRST Championship held May 2011 in the Edward Jones Dome, St. Louis, MO.

\section{Bibliography}


1. Magnum Economic Consulting, LLC. (May 2010). The Region 2000 Partnership and Region 2000's Economy. Retrieved from http:/www.region2000.org/assets/files/EDC/

Region\%202000\%202010\%20ROI\%20report\%20051410.pdf

2. Information Technology Industry Council. (2009). STEM Education. Retrieved from http://www.itic.org/governmentrelations/stem-education/

3. National Research Council. (2011). Successful K-12 STEM Education: Identifying Effective Approaches in Science, Technology, Engineering and Mathematics. Committee on Highly Successful Science Programs for K-12 Science Education. Board on Science Education and Board on Testing and Assessment, Division of Behavioral and Social Sciences and Education. Washington, DC: The National Academies Press.

4. Ohio STEM Learning Network. (n.d.). Retrieved from http://www.osln.org/

5. Drew, D.E. (2011). STEM the tide: reforming science, technology, engineering, and math education in America. Baltimore, MD: The John Hopkins University Press.

6. Berliner, B. (1997). What it takes to work together: the promise of educational partnerships. Knowledge Brief, n14, p. 1.

7. Kanter, R.M. (1994). Collaborative advantage: successful partnerships manage the relationship, not just the deal. Harvard Business Review, July-August, 96-108.

8. Davies, B. \& Hentschke, G. (2006). Public-private partnerships in education: insights from the field. School Leadership \& Management, vol. 26, no. 3, p. 205-226.

9. Klipsch, J.M. (2011). What works in collaboration: a case study of a facilities partnership between a public school district and a nomprofit organization. Doetoral dissertation, University of fowa.

10. Hogue, T. (2007). Community based collaboration: community wellness multiplied. Retrieved from http:// crs.uvm.edu/nnco/collab/ wellness.html

11. Doms, Mark. Chief Economist, U.S. Department of Commerce. (2011, July 13). STEM Workers: Please Live Long and Prosper. Retrieved from http://www.esa.doc.gov/Blog/2011/07/13/stem-workers-pleaselive-long-and-prosper

12. Economics and Statistics Administration, U.S. Department of Commerce. (2011, July 14). STEM: Good Jobs Now and For the Future. Retrieved from http:/www.esa.doc.gov/Reports/stem-good-jobs-now-andfuture

13. LWIA VII Community Profile. (2012, January 4). Region 2000 / Central Virginia. Retrieved from http:// www.alex.vec.virginia.gov/lmi/pdfs/communityprofiles/5115000447.pdf

14. Virginia's Region 2000 Technology Council. (2012). About the Technology Council. Retrieved from http:/www.region2000.org/technology-council.html

15. International Economic Development Council. (2012). Previous IEDC Awards Winners. Retrieved from http://www.iedconline.org/?p=Previous_Winners

16. Central Virginia Community College. (2011). Retrieved from http://www.cvcc.vccs.edu

17. Liberty News Service. (2011, December 29). Google Conducts Case Study of Liberty University Online, Praising their Mobile Advertising. Retrieved from http://www.luonline.com/ index.cfm?PID $=19109 \& \mathrm{mid}=44869$ 
18. Liberty University News Service. (2011, March 26). Liberty makes move to No. 8 in nation. Retrieved from http://www.luonline.com/index.cfm?PID=19109\&mid=27940

19. Virginia's Region 2000 Partnership. (April 2010). Annual Report '09-'10. Retrieved from http:// www.region2000.org/assets/files/R2K\%202010\%20Annual\%20Report\%206.pdf

20. Liberty University. (2012). Retrieved from http://www.liberty.edu

21. platts 2012 Global Energy Awards. (n.d.). Retrieved from http://geaweb.platts.com/ Winners.aspx? $\mathrm{xmlFile}=$ Winners2011.xml

22. AREVA. (n.d.). Retrieved from http://us.areva.com

23. B\&W: thebabcock\&wilcoxcompany. (2012). Retrieved from http://www.babcock.com

24. FLL FIRST LEGO League. (n.d.). Our Founders. Retrieved from http://www.firstlegoleague.org/ mission/founders

25. FLL FIRST LEGO League. (n.d.). Retrieved from http://www.firstlegoleague.org/

26. Region 2000 Technology Council. (2012). Future Focus EXPO. Retrieved from http:// www.techcouncil.us/future-focus-foundation/future-focus-expo/

27. Get Set. (2010). Your Guide to Career Opportunities in Central Virginia. Retrieved from http://getset.cc/

28. Junior FIRST LEGO League. (n.d.). About us. Retrieved from http://www.juniorfirstlegoleague.org/aboutus.html

29. Junior FIRST LEGO League. (n.d.). Retrieved from http://www.juniorfirstlegoleague.org/

30. VEX Robotics Design System. (2012). VEX Robotics Competition. Retrieved from http:// www.vexrobotics.com/competition/vex-robotics-competition/

31. Central Virginia Community College. (2011). 2011 Summer Career Academies. Retrieved from http:// www.cvcc.vccs.edu/Workforce/Tech\%20Prep/201 1\%20Academies.asp

32. Technology Student Association. (2009). TEAMS: Engineering Healthier Lives. Retrieved from http:// teams.tsaweb.org/teams/index.html

33. FIRST LEGO League. (2011). ABC Special, Core Values, Jr. FLL (Press Release: http://bit.ly/qb4Qh2). Retrieved from http://www.firstlegoleague.org/challenge/emailarchive/july2811 
Table 1: SECS Survey for TSA/TEAMS Competition

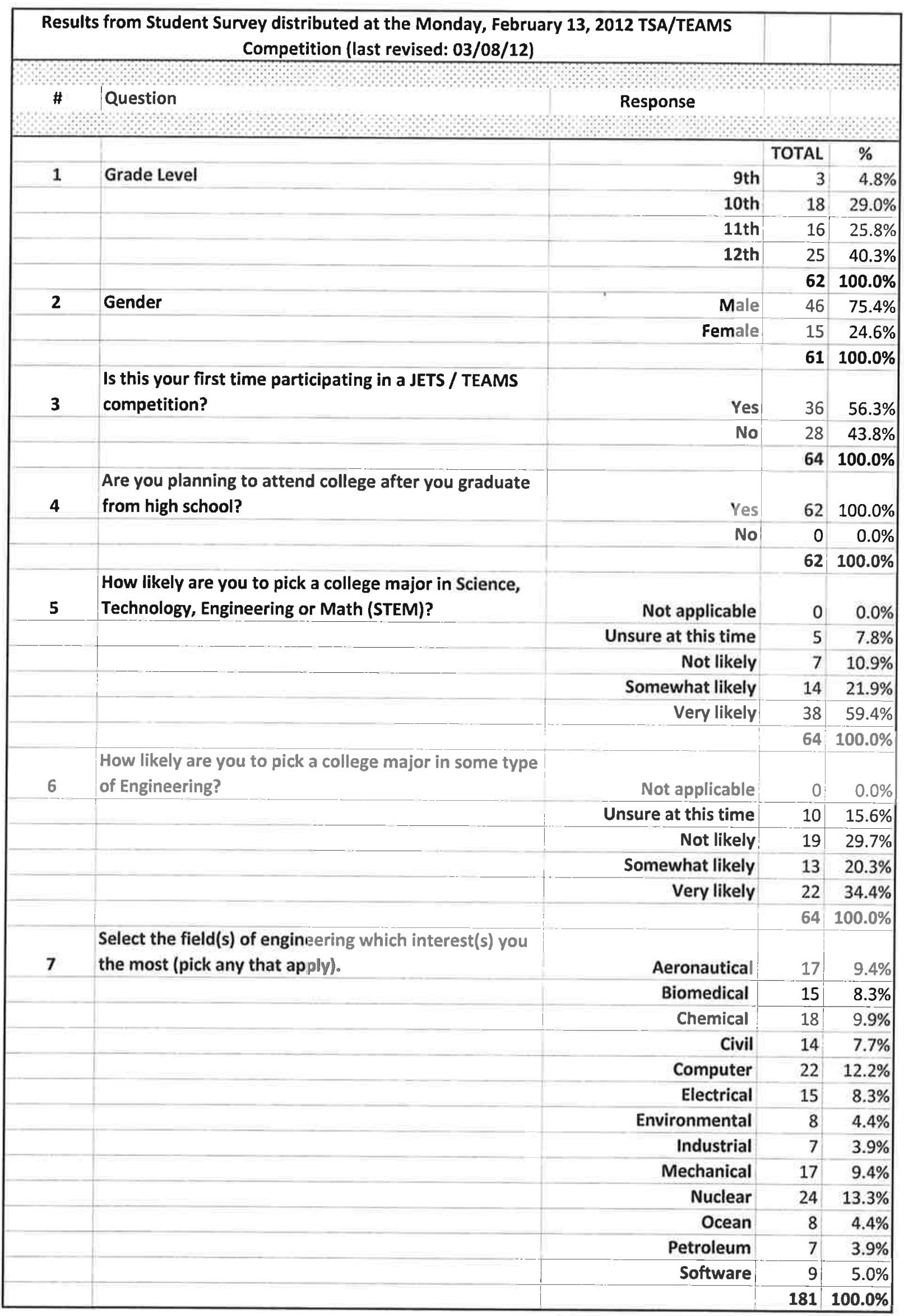


Table 1: SECS Survey for TSA/TEAMS Competition (continued)

\begin{tabular}{|c|c|c|c|c|}
\hline 8 & $\begin{array}{l}\text { How has this competition increased your interest in } \\
\text { engineering? }\end{array}$ & Not at all & 14 & $21.9 \%$ \\
\hline & & A little bit & 22 & $34.4 \%$ \\
\hline & & Somewhat & 22 & $34.4 \%$ \\
\hline & & A great deal & 6 & $9.4 \%$ \\
\hline & & & 64 & $100.0 \%$ \\
\hline \multirow[t]{3}{*}{9} & $\begin{array}{l}\text { Have you ever visited Liberty University before today's } \\
\text { competition? }\end{array}$ & Yes & 48 & $75.0 \%$ \\
\hline & & No & 16 & $25.0 \%$ \\
\hline & & & 64 & $100.0 \%$ \\
\hline \multirow[t]{3}{*}{10} & $\begin{array}{l}\text { Before signing up for this competition, did you know } \\
\text { Liberty University had an engineering program? }\end{array}$ & Yes & 39 & $60.9 \%$ \\
\hline & & No & 25 & $39.1 \%$ \\
\hline & & & 64 & $100.0 \%$ \\
\hline \multirow[t]{5}{*}{11} & $\begin{array}{l}\text { Do you have any interest in attending Liberty } \\
\text { University for college? }\end{array}$ & No way, Jose & 48 & $75.0 \%$ \\
\hline & & I may consider it & 15 & $23.4 \%$ \\
\hline & & I will probably attend & 1 & $1.6 \%$ \\
\hline & & I am planning to attend & 0 & $0.0 \%$ \\
\hline & & & 64 & $100.0 \%$ \\
\hline \multirow[t]{5}{*}{12} & $\begin{array}{l}\text { How did you feel about today's competition (pick any } \\
\text { that apply)? }\end{array}$ & It was boring & 3 & $2.9 \%$ \\
\hline & & It was fun & 37 & $36.3 \%$ \\
\hline & & It was educational & 22 & $21.5 \%$ \\
\hline & & It was challenging & 40 & $39 . \overline{2 \%}$ \\
\hline & & & 102 & $100.0 \%$ \\
\hline \multirow[t]{3}{*}{13} & $\begin{array}{l}\text { Would you recommend this competition to youi } \\
\text { friends? }\end{array}$ & Yes & 58 & $90.6 \%$ \\
\hline & & No & 6 & $9.4 \%$ \\
\hline & & & 64 & $100.0 \%$ \\
\hline \multirow[t]{5}{*}{14} & $\begin{array}{l}\text { What did you like MOST about today's competition } \\
\text { (please only pick one)? }\end{array}$ & Getting out of school & 12 & $18.5 \%$ \\
\hline & & Working as a team & 37 & $56.9 \%$ \\
\hline & Sol & ing problems individually & 3 & $4.6 \%$ \\
\hline & & The material content & 13 & $20.0 \%$ \\
\hline & & & 65 & $100.0 \%$ \\
\hline \multirow[t]{5}{*}{15} & $\begin{array}{l}\text { As a result of this competition, do you feel you have a } \\
\text { better awareness of some of the problems which } \\
\text { engineers must solve? }\end{array}$ & Not really & 3 & $4.7 \%$ \\
\hline & & A little bit & 16 & $25.0 \%$ \\
\hline & & Somewhat & 23 & $35.9 \%$ \\
\hline & & Very much so & 22 & $34.4 \%$ \\
\hline & & & 64 & $100.0 \%$ \\
\hline \multirow[t]{5}{*}{16} & $\begin{array}{l}\text { Which response BEST describes what you think a } \\
\text { career in engineering would be like (please pick one } \\
\text { only)? }\end{array}$ & Boring & 2 & $2.9 \%$ \\
\hline & & Exciting & 13 & $18.6 \%$ \\
\hline & & Difficult & 23 & $32.9 \%$ \\
\hline & & Rewarding & 32 & $45.7 \%$ \\
\hline & & & 70 & $100.0 \%$ \\
\hline
\end{tabular}

